\title{
PELATIHAN INSTALASI LISTRIK BAGI MASYARAKAT PUTUS SEKOLAH DI KABUPATEN MANOKWARI
}

\section{Electrical Installation Training For Communities Disconnecting Schools In Manokwari District}

\author{
Elias K. Bawan
}

Fakultas Teknik Universitas Papua Manokwari

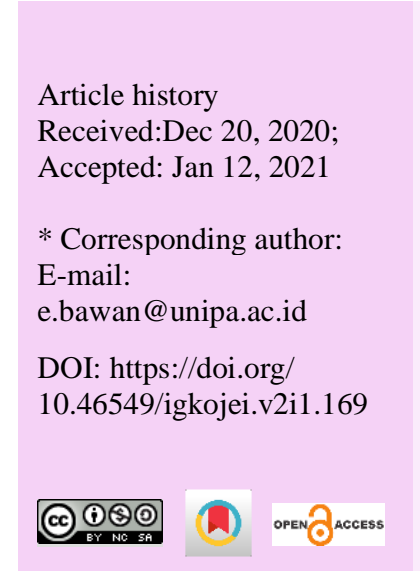

Article history

Received:Dec 20

* Corresponding author:

E-mail:

bawan@unipa.ac.id

DOI: https://doi.org/

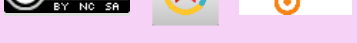

training, and outreach of training alumni to electrical contractors around Manokwari. The training participants managed to plan and install a house installation for a capacity of 450 VA for 3 days at the Electrical Engineering Laboratory at the University of Papua Manokwari.

Keywords: Training; Electrical Installation; Society; PUIL.

\begin{abstract}
ABSTRAK
Kabupaten Manokwari sebagai ibukota provinsi Papua Barat terus melaksanakan pembangunan perkantoran, perumahan dan fasilitas publik lainnya yang membutuhkan energi listrik. Pemasangan instalasi listrik menuntut profesionalisme dan standar yang sesuai dengan peraturan umum instalasi listrik (PUIL). Kebutuhan tenaga instalatur di Manokwari masih sangat terbatas dan di sisi lain terdapat sejumlah siswa dan mahasiswa kelistrikan yang tidak mampu melanjutkan studi oleh karena persoalan biaya sekolah dan kuliah. Kegiatan pengabdian kepada masyarakat ini bertujuan untuk memberikan pelatihan instalasi penerangan bagi masyarakat putus sekolah yang berjumlah 10 orang. Kegiatan pelatihan meliputi sosialisasi kegiatan dan pendaftaran peserta, setting laboratorium, pembekalan peserta, pelatihan dan sosialiasi alumni pelatihan kepada kontraktor listrik disekitar Manokwari. Peserta pelatihan berhasil merencanakan dan memasang instalasi rumah untuk kapasitas 450 VA selama 3 hari di Laboratorium tekn Elektro Universitas Papua Manokwari.
\end{abstract}

Kata kunci: Pelatihan; Instalasi Listrik; Masyarakat; PUIL.

\section{PENDAHULUAN}

Sejak berdiri pada tahun 2005, provinsi Papua Barat dengan ibu kota Manokwari terus mengalami perkembangan di segala bidang kehidupan. Perluasan pemukiman dan pembangunan fasilitas perumahan, perkantoran, umum dan dunia industri serta sarana pendukung lainnya. Seiring 
dengan itu maka kesiapan sumber daya manusia harus mampu menjawab persoalan-persoalan sosial dengan cara menghasilkan sumberdaya manusia yang handal.

Pengembangan fasilitas-fasilitas tersebut tentunya tidak terlepas dari kebutuhan akan energi listrik. Instalasi listrik untuk penerangan atau biasa disebut instalasi penerangan adalah instalasi listrik yang memberi tenaga listrik untuk keperluan penerangan (lampu) dan alat-alat yang lain. Pada akhirnya kebutuhan tenaga profesional di bidang listrik khususnya instalasi penerangan di manokwari akan meningkat pula. Kebutuhan tenaga instalatur pada beberapa Commanditaire Vennootschap (CV) akhirnya mendatangkan tenaga kerja dari luar Papua Barat oleh karena ketersediaan tenaga kerja yang masih terbatas. Kegiatan pelatihan yang berbasis pemberdayaan masyarakat bisa menjadi peluang bagi pemerintah daerah untuk bekerjasama dengan akademisi untuk membekali dan memberikan kegiatan yang bermanfaat bagi masyarakat di wilayahnya secara berkelanjutan (Setiabudi, 2012).

Output sekolah dalam hal ini Sekolah Menengah Kejurusan (SMK) Negeri 2 Manokwari dan Program Studi Teknik Listrik Unipa menjadi harapan, akan tetapi pada beberapa tahun ini terdapat sejumlah siswa dan mahasiswa yang tidak mampu melanjutkan studi oleh karena persoalan biaya sekolah dan kuliah.

Pelatihan ini dimaksudkan untuk membekali peserta dengan pengetahuan tentang instalasi penerangan dan melakukan praktek secara langsung dalam melakukan pemasangan instalasi dengan menggunakan komponen-komponen yang terdapat pada instalasi listrik (sakelar tunggal, sakelar seri, sakelar tukar, kabel dan pipa instalasi dan lain-lain) yang tentunya dengan merencanakan terlebih dahulu instalasi, diagram kawat tunggal maupun diagram pengawatannya sebelum pemasangan. Pelatihan ini mengharapkan para peserta pelatihan akan mampu merencanakan, memasang, menguji dan memeriksa, dan melakukan perawatan terhadap suatu instalasi listrik sebuah rumah/bangunan sesuai dengan standar yang berlaku yaitu Persyaratan Umum Instalasi Listrik 2000 (BSN, 2000).

\section{METODE}

Kegiatan pelatihan dilaksanakan dalam beberapa tahapan selama dua bulan antara lain melaksanakan sosialisasi kegiatan dan pendaftaran peserta, setting laboratorium, pembekalan peserta, pelatihan dan terakhir sosialiasi alumni pelatihan kepada kontraktor listrik disekitar Manokwari.

Peserta yang dilatih dalam pelatihan ini terdiri dari empat kelompok dengan urutan prioritas adalah masyarakat putus sekolah yang datanya diambil dari data SMK Negeri 2 Jurusan Teknik Listrik Kabupaten Manokwari, mahasiswa yang tidak bisa melanjutkan perkuliahan oleh karena keterbatasan biaya uang kuliah dan kelompok yang terakhir adalah masyarakat umum yang memiliki ketertarikan terhadap bidang instalasi dan praktisi yang telah bekerja di beberapa perusahaan lokal di Manokwari. 
Metode pelatihan dibagi dalam dua tahapan yaitu:

1. Pembekalan teori dasar instalasi listrik yang terdiri dari 5 materi antara lain (a) Persyaratan Umum Instalasi Listrik 2000 (b) Pengenalan Kabel dan Bagian-Bagian Instalasi (c) Perlengkapan Hubung Bagi (d) Menghitung Kapasitas Daya Saluran (e) Pemasangan dan Perhitungan Lumen. Perhitungan lumen mengacu pada persamaan (Neidle, 1982). Hasil perhitungan lumen daat dimanfaatkan dalam penentuan tata letak lampu dan jenis lampu yang akan digunakan.

$$
\text { Lumen }=\frac{\text { Iluminasi }(\text { lux }) \times \text { luas bidang kerja }\left(m^{2}\right)}{\text { faktor pemeliharan } x \text { koefisien pemakaian }}=\frac{E \times A}{M F \times C U}
$$

2. Praktek, menggunakan 5 buah modul antara lain (a) Rangkaian Saklar Tunggal dan Seri (b) Rangkaian Saklar Tukar dan Saklar Silang (c) Rangkaian Stop Kontak dan KWH Meter (d) Menggambar Single Line Diagram Rumah Sederhana (e) Instalasi Penerangan Rumah Sederhana. Penyusunan modul pelatihan merujuk pada materi matakuliah di jurusan teknik listrik Unipa dan materi standar pelatihan instalasi listrik lainnya (Suripto, 2017). Peserta dibagi dalam beberapa kelompok dan didampingi oleh beberapa asisten yang diambil dari asisten laboratorium di jurusan Teknik Elektro.

\section{HASIL DAN PEMBAHASAN}

Sosialisasi kegiatan dilaksanakan di beberapa lokasi yaitu Sekolah Menengah Kejuruan (SMK) Negeri 2 Manokwari kepada guru-guru (Gambar 1). Sosialisasi ini sekaligus mendapatkan data jumlah dan nama-nama alumni SMK Negeri 2 Manokwari yang telah lulus tetapi tidak bisa melanjutkan perkuliahan oleh karena keterbatasan biaya uang kuliah.
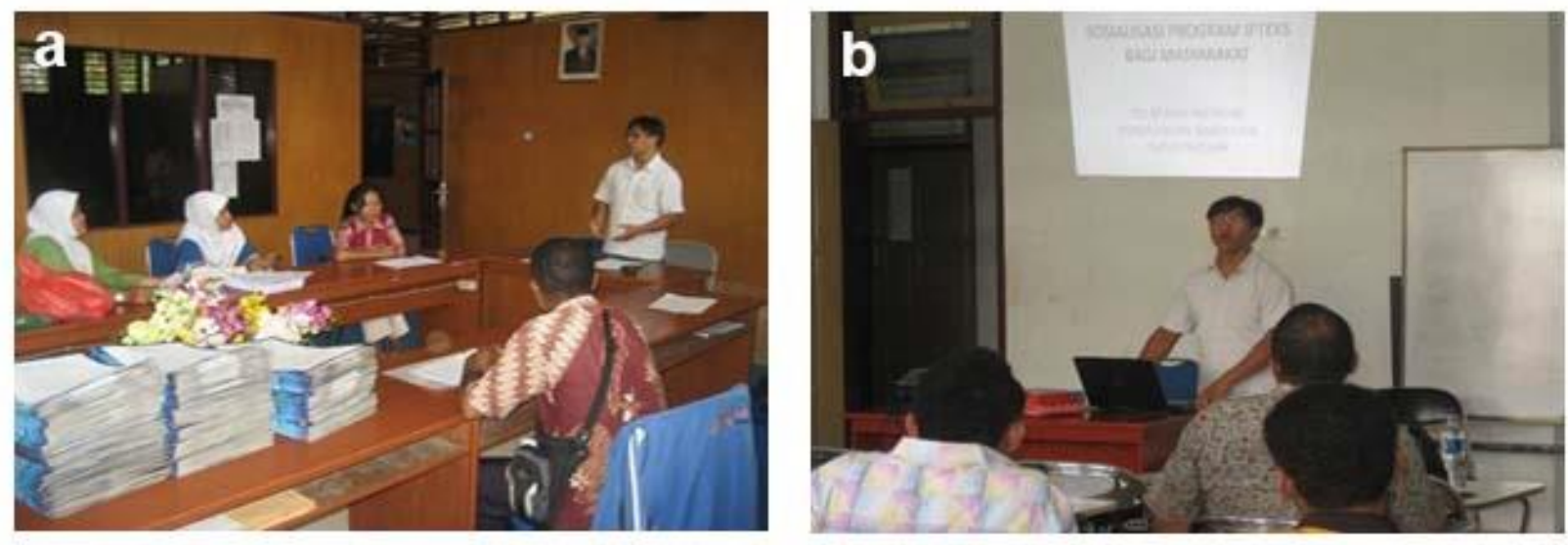

Gambar 1. Sosialisasi (a) di SMK Negeri 2 Manokwari (b) di Prodi Teknik Listrik Unipa

Hasil sosialisasi kepada mitra SMK Negeri 2 Manokwari dan Program Studi D3 Teknik Listrik selain menghasilkan masukan dan saran juga penulis memperoleh beberapa calon peserta pelatihan. Peserta pelatihan ini terdiri dari 10 orang yang terdiri dari 6 alumni SMK Negeri 2 Manokwari yang 
tidak melanjutkan pendidikan ke pendidikan tinggi, mahasiswa drop out dari Diploma Tiga Teknik Listrik sebanyak 2 orang dan 2 orang dari kelompok masyarakat umum.

Penulis melaksanakan setting laboratorium bersama dengan asisten laboratorium jurusan Teknik Elektro. Tujuan dari kegiatan ini adalah untuk menentukan jumlah peralatan dan bahan habis pakai yang akan digunakan. Peserta akan dibagi dalam lima kelompok dan disampingi oleh asisten. Gambar 2a memperlihatkan jenis peralatan dan bahan habis pakai yang akan digunakan selama praktek.

Pelaksanaan kegiatan, penulis bekerja sama dengan beberapa dosen yang jurusan Teknik Listrik Universitas Papua dan guru SMK Negeri 2 Manokwari terkait pemberian teori. Pelaksanaan praktek dibantu oleh beberapa orang asisten di laboratorium jurusan Teknik Elektro Universitas Papua selama tiga hari.
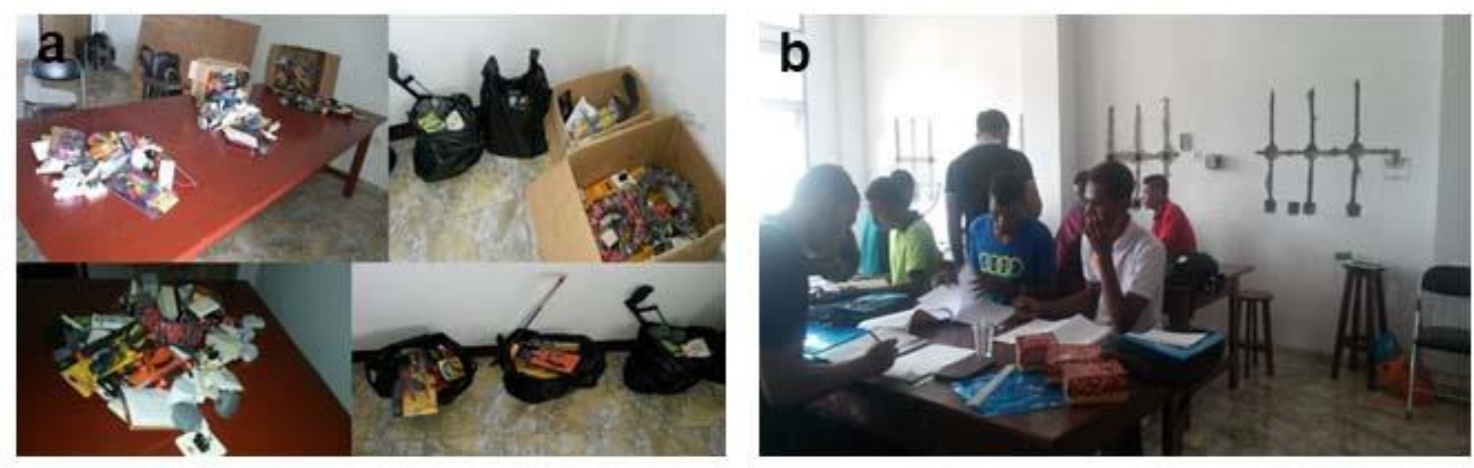

Gambar 2. Persiapan dan pelaksanaan kegiatan. (a) Peralatan dan bahan habis pakai pelatihan (b) Pembekalan teori dan menggambar diagram satu garis dan pengawatan

Setelah peserta menerima pembekalan teori dasar instalasi penerangan dan bagaimana cara menggambar rangkaian diagram instalasi dan pengawatan maka peserta diberi kesempatan untuk melaksanakan praktek dengan pendampingan dari beberapa orang asisten (Gambar 2b). Gambar 3 memperlihatkan peserta pelatihan sedang berdiskusi menentukan dan menghitung komponen instalasi yang akan digunakan seperti jenis dan panjang kabel baik untuk kabel lampu, saklar dan stop kontak dan komponen lainnya sesuai dengan hasil perencanaan yang sudah dikerjakan. 

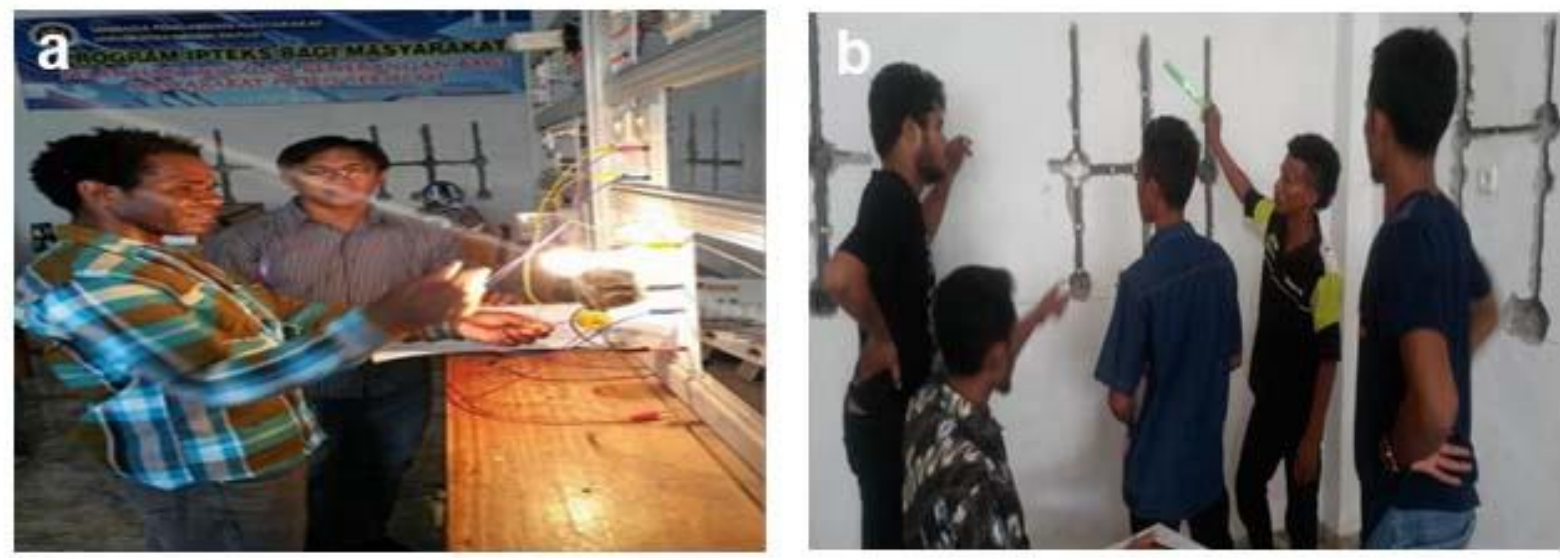

Gambar 3. Teori dan pelaksanaan teori. (a) Pengujian rangkaian, (b) Perhitungan kabel instalasi dan komponen peralatan instalasi

Peserta melaksanakan praktek pemasangan peralatan instalasi berdasarkan hasil gambar perencanaan, peserta didampingi oleh asisten untuk memastikan peserta melaksanakan pemasangan komponen instalasi sesuai dengan standar yang berlaku seperti yang diajarkan pada sesi teori (Gambar 4a). Setelah pengujian baik dari sisi teknik pemasangan dan kualitas tegangan dan arus maka peserta mengabadikan hasil pekerjaan mereka dengan berfoto bersama asisten pendamping (Gambar $4 b)$.
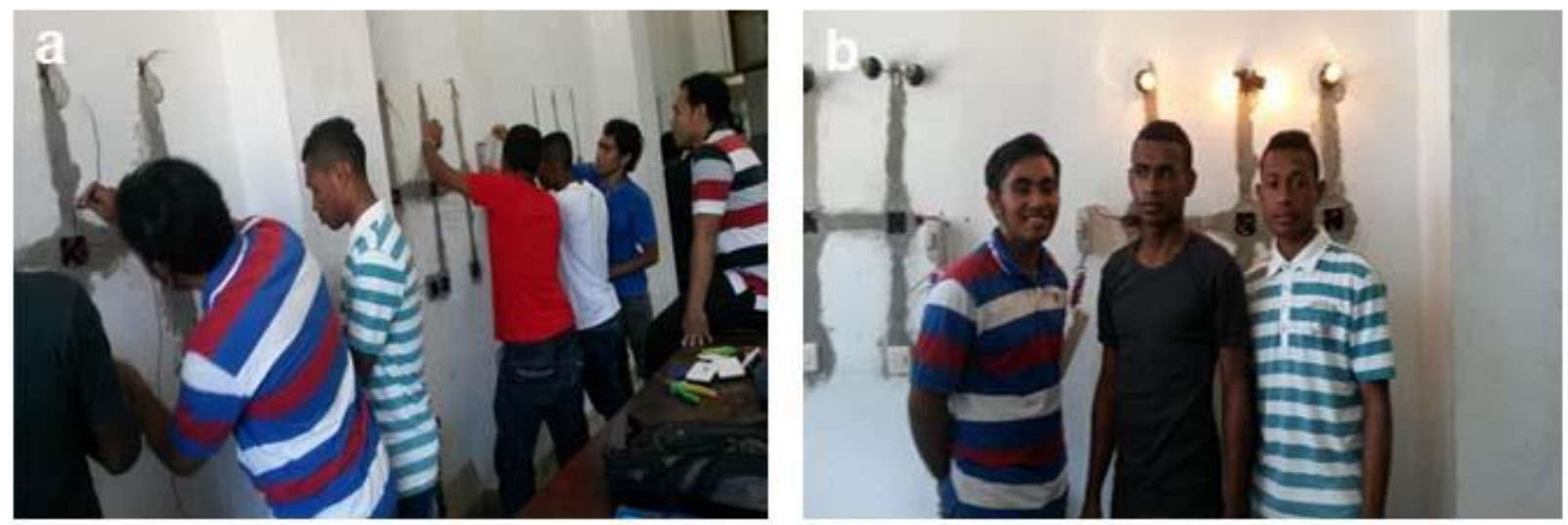

Gambar 4. Praktek dan hasil praktek. (a) Pemasangan komponen instalasi seperti kabel dan stop kontak (b) Foto bersama asisten setelah instalasi berhasil berfungsi dengan baik

Hasil pelatihan instalasi penerangan di sosialisasikan kepada pihak swasta yang bergerak dibidang insalatir termasuk diantaranya di manfaatkan oleh dosen yang memiliki pekerjaan dibidang instalasi rumah tinggal.

Pelatihan yang dilaksanakan secara langsung melibatkan masyarakat kira terus ditingkatkan agar peningkatan keterampilan dan kualitas masyarakat juga meningkat dan bertambah yang pada akhirnya akan membuka lapangan dan mengurangi pengangguran yang pada akhirnya dapat meningkatkan taraf kesejahteraan masyarakat. Hal lain yang bisa dihasilkan adalah kelayakan 
instalasi penerangan menjadi lebih baik karena dikerjakan oleh tenaga instalatir yang terlatih (Indrawati, 2017).

\section{KESIMPULAN}

Setelah melaksanakan pelatihan instalasi penerangan bagi masyarakat putus sekolah, di dapatkan beberapa kesimpulan antara lain:

1. Perserta pelatihan mendapatkan pengetahuan dan keterampilan memasang instalasi listrik tegangan rendah (220 volt).

2. Peserta pelatihan dapat merencanakan dan memasang instalasi rumah tinggal $450 \mathrm{VA}$.

3. Peserta mendapatkan sertifikat dan peralatan dasar yang dapat dijadikan modal dalam mencari pekerjaan di bidang instalatir.

\section{UCAPAN TERIMA KASIH}

Ucapan terima kasih disampaikan kepada Direktorat Penelitian dan Pengabdian kepada Masyarakat Direktorat Jenderal Penguatan Riset dan Pengabdian Masyarakat yang telah membiayai melalui Program Ipteks bagi Masyarakat (IbM). Ucapan yang sama disampikan kepada SMK Negeri 2 Manokwari dan Program Studi D3 Teknik Listrik Universitas Papua.

\section{DAFTAR PUSTAKA}

BSN, B. S. (2000). Persyaratan Umum Instalasi Listrik 2000 (PUIL 2000). Jakarta: Badan Standarisasi Nasional.

Indrawati, E. M. (2017). Pelatihan Instalasi Listrik Rumah Tinggal Bagi Pemuda Karang Taruna Desa Pelem Kecamatan Pare Kabupaten Kediri. Seminar Nasional hasil Pengabdian Kepada Masyarakat (SENIAS) 2017 (hal. 124-129). Madura: Universitas Islam Madura.

Laboratorium Tenaga Teknik Elektro. (t.thn.). Modul Praktikum Instalasi Listrik. Semarang: Fakultas Teknologi Industri Universitas islam Sultan Agung .

Neidle, M. (1982). Teknologi Instalasi Listrik. Jakarta: Erlangga.

Setiabudi, R. I. (Novemmber 2012). Pealtihan Instalasi Listrik Tegangan Rendah Untuk Meningkatkan Keterampilan Anak Putus Sekolah (Studi Kasus di Pajijahan Bogor). Jurnal Aplikasi Ipteks untuk Masyarakat, 80-86.

Suripto, S. (2017). Teknik Instalasi Listrik. Yogyakarta: Fakultas Teknik Universitas Muhammadiyah Yogyakarta. 